\title{
Analisis Kelayakan Usahatani Jagung Pipilan di Kecamatan Peureulak Kabupaten Aceh Timur
}

\author{
Ramini ${ }^{*}$, Silvia Anzitha ${ }^{2}$ \\ 1,2 Prodi Agribisnis Fakultas Pertanian Universitas Samudra, Indonesia. \\ *Corresponding author's e-mail: silvianzitha@unsam.ac.id
}

\begin{abstract}
ABSTRAK
Tujuan penelitian ini untuk mengetahui kelayakan usahatani jagung pipilan Di Kecamatan Peureulak Kabupaten Aceh Timur. Penelitian ini menggunakan metode survey dan teknik pengambilan sampel menggunakan metode simple random sampling. Pengambilan sampel ditetepkan $25 \%$ dari populasi yang berjumlah 62 orang dan total sampel berjumlah 30 orang. Hasil analisis finansial usahatani jagung pipilan di Kecamatan Peureulak dari sisi R/C Ratio diperoleh nilai sebesar 3,47 (layak). BEP Rupiah sebesar sementara total biaya riil jagung pipilan di Kecamatan Peureulak adalah 1.151,96 (layak) BEP jumlah produksi sebesar 106,48 sementara produksi riil usahatani jagung pipilan di Kecamatan Peureulak adalah sebesar $3.697,73 \mathrm{Kg}$ (layak) daerah.
\end{abstract}

Kata Kunci:

BEP; R/C ratio; jagung; finansial

\begin{abstract}
The aim of this research to know the feasibility of corn Aceh development plantation focused in regional potential commodity development. The development to supported livelihood society dan agroindustry growth. This research did in Aceh with survey method and the analysis used hierarki model, LQ, investment criteria, specialization and diversification. Result showed that Aceh plantation development wasn't suitable with potential production center in each district. The prime commodity in Aceh such as palm oil, coffee, cocoa, rubber, coconut and areca have been people mainstay as a source of livelihood in plantation sector. Main strategy from commodity development in Aceh wa a diversification strategy based on potential combination, commodity type and infrastructure to support agribusiness. Every district develop some commodity to anticipate price fluctuation.
\end{abstract}

Keywords:

LQ; plantation; revitalization; strategy

How to Cite: Ramini, Silvia Anzitha. (2019). Analisis Kelayakan Usahatani Jagung Pipilan di Kecamatan Peureulak Kabupaten Aceh Timur. Jurnal Penelitian Agrisamudra. 6(1): 48-54 


\section{Pendahuluan}

Jagung pipilan merupakan komoditas palawija utama di Indonesia ditinjau dari aspek pengusahaan dan penggunaan hasilnya, yaitu sebagai bahan baku pangan dan pakan. Kebutuhan jagung terus meningkat seiring dengan meningkatnya permintaan bahan baku pakan. Komposisi bahan baku pakan ternak unggas membutuhkan jagung pipilan sekitar 50 persen dari total bahan yang digunakan (Sarasutha,2002).

Jagung pipilan merupakan salah satu jenis tanaman pangan yang dapat prioritas untuk dikembangkan karena kedudukannya disamping sebagai bahan baku utama industri pakan ternak dan industri lainnya, sehinggga mempunyai potensi yang besar untuk meningkatkan pendapatan petani, serta merupakan komoditas penting dalam upaya diversifikasi pangan. Selain itu juga jagung pipilan merupakan sumber utama karbohidrat dan protein.

Jagung pipilan merupakan komoditas utama tanaman pangan yang mempunyai peranan strategis dalam pembangunan pertanian dan perekonomian nasional. Salah satu daerah Aceh yang membudidayakan jagung pipilan adalah Aceh Timur. Komoditas ini mempunyai fungsi multiguna, baik untuk konsumsi langsung maupun sebagai bahan baku utama industri pakan dan industri pangan. Kecamatan Peureulak merupakan salah satu daerah penghasil jagung pipilan kering di Aceh Timur. Jagung pipilan yang dalam proses panen tidak seperti panen jagung manis. Panen jagung pipilan dilakukan saat tongkol jagung sudah kering ditanaman lalu jagung pipilan tersebut dipetik dan dipisahkan antara biji dan tongkol menggunakan mesin treser.

Kabupaten Aceh Timur merupakan salah diantara Kabupaten-Kabupaten yang ada di Provinsi Aceh yang memiliki 24 Kecamatan dari 24 Kecamatan hanya 23 Kecamatan yang memiliki tanaman jagung pipilan. Luas lahan usahatani jagung pipilan di Kecamatan Peureulak Kabupaten Aceh Timur adalah sebesar $73 \mathrm{Ha}$, produksi 372 Ton dengan produktivitas 39.8 Ton/Ha. Luas lahan terbesar terdapat di Desa Blang Bitra yaitu sebesar 16 ha, dengan produksi 55 Ton sedangkan produktivitas yaitu sebesar 3.44 Ton/Ha. Sedangkan luas lahan usahatani jagung pipilan terkecil terdapat di Desa Blang Batee sebesar 2 Ha dan produksi 8 Ton dengan produktivitas 4 Ton/Ha. Petani jagung pipilan di Kecamatan Peureulak dalam menjalankan usahataninya belum pernah menghitung kelayakan usahataninya, sehingga petani belum mengetahui secara pasti apakah usahatani yang di jalankan layak atau tidak untuk dikerjakan.

Produksi jagung pipilan dari tahun 2015 ke tahun 2017 mengalami peningkatan produksi, pada tahun 2015 produksi jagung pipilan sebanyak 6.749 Ton mengalami peningkatan produksi sebanyak 65,880 Ton di tahun2017, di tahun 2017 di Aceh Timur memproduksi jagung pipilan sebanyak 72,629 Ton. Penyebab tinggi rendahnya produksi jagung pipilan salah satunya dapat dilihat dari permasalahan dilapangan, diantaranya tersedianya atau penyiapan bibit dan kualitas bibit jagung pipilan.

Pembudayaan tanaman jagung pipilan diharapkan dapat memiliki tingkat keuntungan yang maksimal bagi petani, karena disamping memberikan pendapatan kepada petani dan keluarga, serta kepada masyarakat sekitanya. Pendapatan yang diperoleh petani 
diharapkan dapat menjamin petani untuk melangsungkan kegiatan usahataninya, untuk melihat suatu usahatani layak dijalankan atau tidak dapat dilakukan dengan menggunakan analisis kelayakan. Sehubungan dengan uraian diatas, maka penulis tertarik untuk melakukan penelitian yang terkait dengan "analisis kelayakan usahatani jagung pipilan di Kecamatan Peureulak Kabupaten Aceh Timur".

\section{Metode Penelitian}

Lokasi yang dipilih untuk penelitian ini adalah Kecamatan Peureulak Kabupaten Aceh Timur dengan metode Survey. Kecamatan Peureulak Kabupaten Aceh Timur terdiri 38 desa tetapi hanya 10 desa yang memiliki usahatani jagung pipilan. Dari 10 desa tersebut di ambil 5 secara Purpossive sampling. Adalah sampling yang dilakukan dengan pertimbangan tertentu. Desa-desa yang dipilih dalam penelitian ini dengan pertimbangan bahwa ke 5 desa tersebut yang memiliki produksi tertinggi, desa-desa tersebut adalah desa Blang Bitra, Tualang, Blang Simpo, Blang Batee, Uteun Dama. Pengambilan petani sampel dilakukan dengan menggunakan metode simple random sampling jumlah populasi petani jagung pipilan didaerah penelitian yaittu berjumlah 62 orang yang terdiri dari Desa Tualang sebanyak 20 orang, Desa Blang Bitra sebanyak 10 orang, Desa Blang Batee sebanyak 10 orang, Desa Uteun Dama sebanyak 12 orang, Desa Blang Simpo sebanyak 10 orang. Dari populasi tersebut diambil 25\% sebanyak 30 petani sampel yang terdiri dari Desa Tualang 7 orang, Desa Blang Bitra 3 orang, Desa Blang Batee 7 orang, Desa Uteun Dama 7 orang Desa Blang Simpo 6 orang.

Untuk mengetahui biaya total (Total Cost) menggunakan rumus sebagai berikut :

$\mathrm{TC}=\mathrm{TFC}+\mathrm{TVC}$

Keterangan

$\mathrm{TC} \quad=$ Total Cost (Total Biaya)

$\mathrm{TFC}=$ Total Fixed Cost (Biaya Tetap)

TVC $=$ Total Variabel Cost (Biaya Variabel)

Penerimaan dihitung dengan rumus sebagai berikut :

$\mathrm{TR}=\mathrm{Y} \times \mathrm{Hy}$

Keterangan

$\mathrm{TR}=$ Total Revenue (Total Penerimaan)

$\mathrm{Y} \quad=$ Produksi yang dihasilkan

Hy = Harga satuan

Sedangkan untuk mengetahui pendapatan bersih digunakan rumus sebagai berikut: $\mathrm{P}=\mathrm{TR}-\mathrm{TC}$

Keterangan

$\mathrm{P} \quad=$ Pendapatan Usahatani

TR = Total Penerimaan (Total Revenue)

$\mathrm{TC} \quad=$ Total Biaya (Total Cost) 
Untuk mengetahui apakah usahatani jagung pipilan tersebut menguntungkan atau merugikan dapat digunakan rumus sebagai berikut :

RC Ratio $=$ TR $/ \mathrm{TC}$

Keterangan

$\mathrm{R} / \mathrm{C}=$ Reveneu Cost Ratio

TR = Total Penerimaan (Total Revenue)

$\mathrm{TC} \quad=$ Total Cost (Total Biaya)

Kriteria

- Jika nilai R/C Ratio lebih besar dari satu, maka usahatani layak untuk diusahakan.

- Jika nilai R/C Ratio kurang dari 1,5 maka usahatani tidak di usahakan.

- Jika nilai $R / R$ Ratio = 1,5 maka usahatani tidak memperoleh keuntungan dan kerugian (impas)

Untuk menghitung BEP dapat menggunakan rumus sebagai berikut :

BEP dalam $(Q)=T C P$ (Ibrahim, 1998)

$$
\mathrm{Q}=
$$
Unit

Untuk menghitung BEP dalam rupiah adalah mengalikan dengan harga per unit produksi.

BEP dalam $(\mathrm{Rp})=\mathrm{TCP}$..........(Ibrahim, 1998)

Dimana :

$$
=\operatorname{Rp} \ldots . . . .
$$

$\mathrm{TC}=$ Total Biaya $($ Total Cost $)$

$\mathrm{P}=$ Harga per unit

Kriteria

- Jika produksi dan harga < BEP usaha tidak layak diusahakan.

- Jika produksi dan harga > BEP usaha layak diusahakan.

\section{Hasil dan Pembahasan}

\subsection{Produksi Jagung Pipilan}

Produksi yang dihasilakan dapat diukur dalam bentuk fisik yaitu dalam tongkol jagung pipilan. Rata-rata produksi usahatani jagung pipilan di Kecamatan Peureulak dapat dilihat pada tabel 1 berikut ini

Tabel 1. Produksi jagung pipilan

\begin{tabular}{llr}
\hline No & \multicolumn{1}{c}{ Desa Sampel } & Produksi $(\mathrm{Kg} / \mathrm{UT} / \mathrm{MT})$ \\
\hline 1 & Tualang & $3.024,29$ \\
2 & Blang Bitra & $12.015,66$ \\
3 & Blang Batee & $3.124,71$ \\
4 & Uteun Dama & $2.867,57$ \\
5 & Blang Simpo & $1.955,33$ \\
\hline & Rata-rata & $3.697,73$ \\
\hline
\end{tabular}

Sumber: data primer

Dari tabel di atas dapat dilihat rata-rata produksi usahatani jagung pipilan di Kecamatan Peureulak, yaitu sebesar $3.697,73 \mathrm{Kg} / \mathrm{UT} / \mathrm{MT}$ rata-rata produksi tertinggi terdapat di 
Desa Blang Bitra yaitu sebesar 12.015,66Kg/UT/MT dan rata-rata produksi terendah terdapat di Desa Blang Simpo yaitu sebesar $1.955 \mathrm{Kg} / \mathrm{UT} / \mathrm{MT}$.

Nilai Produksi (Penerimaan ) adalah total perkalian produksi dan hasil produksi yang diterima oleh petani dari usahataninya. Besarnya nilai produksi sangat ditentukan oleh harga yang berlaku saat petani menjual hasil produksinya. Berdasarkan hasil penelitian harga jual jagung pipilan di Kecamatan Peureulak yaitu sebesar Rp 4.000. Per kilogram. Rata-rata nilai produksi usahatani jagung pipilan di Kecamatan Peureulak dapat dilihat pada tabel 2 berikut ini.

Tabel 2. Nilai roduksi jagung pipilan

\begin{tabular}{llr}
\hline No & \multicolumn{1}{c}{ Desa Sampel } & Nilai Produksi $(\mathrm{Kg} / \mathrm{UT} / \mathrm{MT})$ \\
\hline 1 & Tualang & $12.097 .142,85$ \\
2 & Blang Bitra & $46.062 .666,66$ \\
3 & Blang Batee & $12.494 .857,15$ \\
4 & Uteun Dama & $11.478 .285,71$ \\
5 & Blang Simpo & 7.821 .333 .33 \\
\hline & Rata-rata & $14.793 .000,00$ \\
\hline
\end{tabular}

Sumber: data primer

Tabel 2 diatas dapat dilihat bahwa rata-rata nilai produksi ( Penerimaan ) usahatani jagung pipilan di Kecamatan Peureulak yaitu sebesar Rp 14,793.000,00 per UT/MT. Penapatan terbesar terdapat di Desa Blang Bitra yaitu sebesar Rp 48.062.666,66 per UT/MT dan pendapatan terkecil terdapat di Blang Simpo yaitu sebesar Rp 77.821.333,33 per UT/MT.

Pendapatan yang dianalisis dalam penelitian ini adalah pendapatan bersih.pendapatan bersih adalah besarnya total penerimaan petani dari hasil penjualan jagung pipilan dikurangi total biaya produksi yang dikeluarkan. Untuk pendapatan bersih atau keuntungan petani jagung pipilan di Kecamatan Peureulak dapat dilihat pada tabel 3 berikut :

Tabel 3. Pendapatan produksi jagung pipilan

\begin{tabular}{llr}
\hline No & \multicolumn{1}{c}{ Desa Sampel } & Produksi $(\mathrm{Kg} / \mathrm{UT} / \mathrm{MT})$ \\
\hline 1 & Tualang & $8.368 .255,99$ \\
2 & Blang Bitra & $44.697 .088,55$ \\
3 & Blang Batee & $8.530 .309,75$ \\
4 & Uteun Dama & $7.723 .470,19$ \\
5 & Blang Simpo & $4.304 .290,66$ \\
\hline & Rata-rata & $11.075 .900,70$ \\
\hline
\end{tabular}

Sumber: data primer

Tabel 3 diatas dapat dilihat bahwa rata-rata pendapatan bersih usahatani jagung pipilan di Kecamatan Peureulak yaitu sebesar Rp 11.075.900,70 per UT/MT. Pendapatan terbesar terdapat pada Desa Blang Bitra yaitu sebesar Rp 44.697.088,55 per UT/MT dan 
pendapatan bersih terkecil yaitu terdapat di Desa Blang Simpo yaitu sebesar Rp 4.304.290,66 per UT/MT.

\subsection{Analisis Finansial Usahatani Jagung Pipilan di Kecamatan Peureulak.}

Analisis Finansial usahatani jagung pipilan di Kecamatan Peureulak diperoleh hasil sebagai berikut :

Tabel 4. Hasil analisis finansial usahatani jagung pipilan

\begin{tabular}{llrrr}
\hline No & \multicolumn{1}{c}{ Kriteria } & \multicolumn{1}{c}{ Riil (A) } & \multicolumn{1}{c}{ BEP (B) } & \multicolumn{1}{c}{ Keputusan } \\
\hline 1 & R/C Ratio & 3,47 & 1,5 & A >B (Layak) \\
2 & BEP Rupiah & $4.259 .565,19$ & $1.151,96$ & A > B (Layak) \\
3 & BEP Produksi & $3.967,73$ & 106,48 & A >B (Layak) \\
\hline
\end{tabular}

Sumber: data primer

Tabel 4 menjelaskan bahwa :

- Usahatani jagung pipilan di Kecamatan Peureulak jika dilihat dari sisi R/C Ratio diperoleh nilai sebesar $3.47>1,5$ yang artinya setiap pengeluaran biaya Rp. 1 akan mendapatkan penerimaan sebesar Rp. 3,47 maka usahatani jagung pipilan di Kecamatan Peureulak layak untuk diusahakan.

- Usahatani jagung pipilan di Kecamatan Peureulak diperoleh dari BEP rupiah yaitu sebesar 1.151,96 sementara penerimaan riil jagung pipilan di Kecamatan Peureulak adalah sebesar $\mathrm{Rp} 4.259 .565,19$. berarti penerimaan riil lebih besar dari BEP penerimaan, sehingga dapat disimpulkan bahwa usahatani jagung pipilan di Kecamatan Peureulak Layak diusahakan dari sisi penerimaan jagung pipilan.

- Usahatani jagung pipilan di Kecamatan Peureulak diperoleh BEP jumlah produksi sebesar 106,48 sementara produksi riil usahatani jagung pipilan di Kecamatan Peureulak adalah sebesar 3.697,73 Kg. Berarti jumlah produksi riil lebih besar dari BEP jumlah produksi, sehingga dapat disimpulkan bahwa usahatani jagung pipilan di Kecamatan Peureulak layak diusahakan dari sisi BEP jumlah produksi atas dasar biaya tetap.

\section{Kesimpulan}

Hasil analisis finansial usahatani jagung pipilan di Kecamatan Peureulak dari sisi R/C Ratio (perbandingan penerimaan dan biaya ) diperoleh nilai sebesar 3,47 (layak). BEP Rupiah sebesar Rp 1.151,96 sementara total biaya riil jagung pipilan di Kecamatan Peureulak adalah 4.259.565,19 (layak). BEP jumlah produksi sebesar 106,48 , sementara produksi riil usahatani jagung pipilan di Kecamatan Peureulak adalah sebesar 3.697,73 Kg (layak)

\section{Daftar Pustaka}

AAK.2001. Tenik Bercocok Tanam jagung. Yogyakarta. Penerbit Kanisius (Ikatan IKAPI).

Aksi Agraria Kanisius. 1993. Teknik Bercocok Tanam Jagung. Kanasius. yogyakarta Arikunto, S. 2006. Prosedur penilitian suatu pendekatan peraktek. Rineka Cipta. Jakarta

Balai Pertanian Tanaman Perkebunan dan Serat. 2014. Kualitas Penggunaan dan Pengaplikasian Bibit, Bogor.

Daniel, M. 2004. Pengantar Ekonomi Pertanian. Bumi Aksara. Jakarta. 
Fahrrozi. 2004. Pemeliharaan budidaya Tanaman Hortikultura, Penebar Swadaya : Jakarta. Faturochma. 2004. Dinamika kedudukan dan kebijakan. Universitas Gadjah Mada. Pusat Studi Dinamika Kedudukan dan Kebijakan. Yogyakarta.

Hernanto, fadholi. 2001. Ilmu Usahatani. Penebar Swadaya, Jakarta

Mubyarto. 2012. Pengantar Ekonomi Pertanian. LP3ES. Jakarta

Nazir, M. 2005. Metode Penelitian. Ghalia Indonesia. Jakarta.

Pratiwi, L. 2009. Margalisasi Pekerjaan Dalam Industri dan Pengaruhnya Terhadap Kesejahteraan Keluarga. Skripsi. Departemen Sains Komunikasi dan Pengembangan Masyarakat Fakultas Ekologi Manusia Institut Pertanian Bogor.

Soekartawi. 2002. Ilmu Usahatani. UI Press, Jakarta.

Soekartawi. 2002. Agribisnis Teori dan Aplikasinya. Rajawali Pers, Jakarta.

Sugiyono. 2008. Penelitian Kuantitatif dan kualitatif. PT Ghalia Indonesia. Jakarta.

Suratiyah.K, 2008. Ilmu Usahatani. Penebar Swadaya. Jakarta 